\title{
Predicting Soil Erosion Status of the Düz Creek Watershed
}

\section{in Artvin}

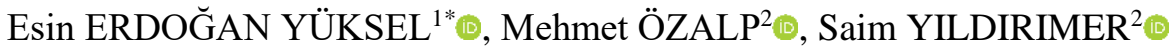

${ }^{1}$ Bursa Technical University, Faculty of Forestry, Department of Forest Engineering, Bursa, TURKEY

${ }^{2}$ Artvin Çoruh University, Faculty of Forestry, Department of Forest Engineering, Artvin, TURKEY

*Corresponding author: esin.yuksel@btu.edu.tr

Received Date: 02.04.2019

Accepted Date: 19.08.2019

\begin{abstract}
Aim of study: Main objective of this research was to predict some of the processes (soil loss, runoff and
\end{abstract} sediment yield) related to soil erosion with the help of WEPP (Water Erosion Prediction Project) model.

Area of study: The WEPP model was applied to the Düz Creek Watershed (1059 ha in size). It is a subwatershed flowing into the greater Çoruh River Basin near the district of Borçka, Artvin.

Material and methods: As required by the WEPP model, four large-data files of soil, climate, slope and plant cover/management were created for the watershed using the data gathered from in-field samplings (soil), laboratory analyses and GIS (Geographical Information Systems) assessments. For easier run and detailed investigation of soil erosion process of the research area, the studied watershed was divided into eight small hydrological units (SHUs) and the program was run on these SHUs.

Main results: At the end of GeoWEPP's run, the results revealed that a total of about $735 \mathrm{~mm}$ annual precipitation was fell within the study area. The model also predicted that there was approximately $207 \mathrm{~mm}$ as runoff out of this amount of precipitation, which, in turn, generated an annual total soil loss and sediment amounts as $2815.2 \mathrm{t}$ and $2720.9 \mathrm{t}$, respectively. In addition, the sediment yield per unit area was estimated to be around $2.57 \mathrm{ton} / \mathrm{ha} / \mathrm{yr}$ while the sediment delivery ratio (SDR) was found to be as 0.977 . Lastly, the model predicted that the particle distribution of eroded sediment were $20 \%, 25 \%$ and $55 \%$ of clay, silt and sand, respectively, while the mean organic matter (OM) amount of the lost sediment was about $5 \%$ for the studied watershed.

Highlights: Soil loss and sediment yield can be calculated for large areas in a short time and with little cost.

Keywords: Soil Loss, Sediment Yield, Watershed, GeoWEPP Model, Artvin.

\section{Artvin Düz Dere Havzası'nda Toprak Erozyonu Durumunun}

\section{Tahmini}

\section{$\ddot{\mathbf{O} z}$}

Çalışmanın amacı: Havzada oluşan toprak kaybı ve sediment veriminin WEPP modeli ve CBS (Coğrafi Bilgi Sistemleri) tekniklerinin entegre edildiği GeoWEPP arayüzü kullanılarak kısa sürede ve az masrafla hesaplanması amaçlanmıştır.

Çalışma alanı: Çoruh nehrine birleşen Düz Dere Havzası araştırma alanı olarak seçilmiştir.

Materyal ve yöntem: GeoWEPP ara yüzü için gerekli olan iklim, eğim ve bitki amenajmanı dosyalarına ek olarak toprak dosyası oluşturulmuştur. Araştırma havzası sekiz alt havzaya bölünmüş ve program bu alt havzalarda yürütülerek toprak kaybı, yüzeysel akış ve sediment veriminin ortalama değerleri hesaplanmıştır.

Sonuçlar: Çalışma sonucunda, havzaya 735 mm'lik yağış düştüğü ve bunun yaklaşık olarak 207 mm'sinin yüzeysel akışa geçtiği tahmin edilmiştir.1059 ha'lık bir alana sahip olan havzada yıllık toplam toprak kaybı ve sediment miktarı sırası ile 2815.2 ve 2720.9 ton olarak bulunmuştur. Bununla beraber, birim alandan ise 2.57 ton/ha/yıl sediment verimi gerçekleştiği hesaplanmıştır. Ortalama sediment iletim oranı yaklaşık 0.977 olarak bulunmuştur. Ek olarak, taşınan sediment içerisindeki ortalama kil oranının \% 20 , toz oranının $\% 25$, kum oranının $\% 55$, organik madde miktarının ise $\% 5$ olduğu tahmin edilmiştir.

Önemli vurgular: Toprak kaybı ve sediment verimi, büyük alanlar için kısa sürede ve daha az maliyetle hesaplanabilir.

Anahtar Kelimeler: Toprak Kaybı, Sediment Verimi, Havza, GeoWEPP, Artvin. 


\section{Introduction}

Soil erosion is one of the most important environmental problems in our country ranking near the top in the world with a soil loss of approximately 642 million tons per year (Anonymous, 2018). Soil erosion occurring under the influence of many factors is very difficult to measure due to temporal and financial difficulties; thus it can only be predicted especially for large areas.

To avoid these disadvantages, the use of Geographic Information Systems (GIS) along with the developing technology contributes to the prediction with the help of mathematical relationships by storing the data necessary for the models used to predict erosion (Başyiğit and Dinç, 2003). In addition, determining the risky areas where erosion occurs with the help of GIS and detecting the priority areas for protection provide great advantages for updating similar studies that will be carried out in the future. Therefore, firstly began with Universal Soil Loss Equation (USLE), the studies of predicting erosion on a watershed base using computers and GIS techniques along with the modeling methods have been increasing lately (Wischmeier and Smith, 1965; Flanagan and Nearing, 1995; Foster and Lane, 1987; Nearing, Foster, Lane \& Finger, 1989).

The Water Erosion Predict Project (WEPP) model, one of the modeling methods, has been used frequently in recent years. Especially the applicability and financial contribution of the GeoWEPP interface which is used as integrated with GIS bring the use of erosion prediction models forward (Flanagan and Livingston, 1995; Hacısalihoğlu, Kalay \& Oktan, 2008).

The WEPP erosion model is a continuous simulation model which is capable of predicting the temporal and spatial distribution of net soil loss and accumulation in large scale where complex topographic structure can be determined with the Digital Elevation Model (DEM) (Ascough II, Nearing, Baffaut \& Liu, 1997; Baffaut, Nearing, Ascough II \& Liu, 1997; Flanagan and Nearing, 1995). GeoWEPP program integrating GIS, WEPP, and TOPAZ programs provides opportunities for predicting soil erosion especially in large watersheds as it makes the organization of complex data easier. In addition to GeoWEPP, TOPAZ and the programs used by TOPAZ while running are also used in determining the topographical properties of the watershed (Garbrecht and Martz, 1999).

In this study, Düz Creek Watershed within the Eastern Black Sea Region was selected for the implementation of the model because this region involves the zones with high erosion risk due to its steep land structure, emerging as one of the areas where the use of erosion prediction models is required. It is quite important to know how much soil loss may occur from the watershed because of the problems caused by the sediment carried by water erosion.

The main purpose of this study was to measure the amounts of soil loss and sediment yield occurring in the Düz Creek Watershed in a timely and reliable way using GeoWEPP interface. Besides, it was also aimed to prepare the basic ground for the practitioners who carry out activities for the prevention of erosion by examining the soil erosion phenomenon on the basis of the watershed and to guide the watershed planners regarding the determination of priority areas for protection.

\section{Materials and Methods}

The Düz Creek Watershed is located within the boundaries of Artvin Province, Borçka, and central district. It extends in the southwest-northeast direction for approximately $6 \mathrm{~km}$ long (Figure 1). The average elevation is $917 \mathrm{~m}$. 


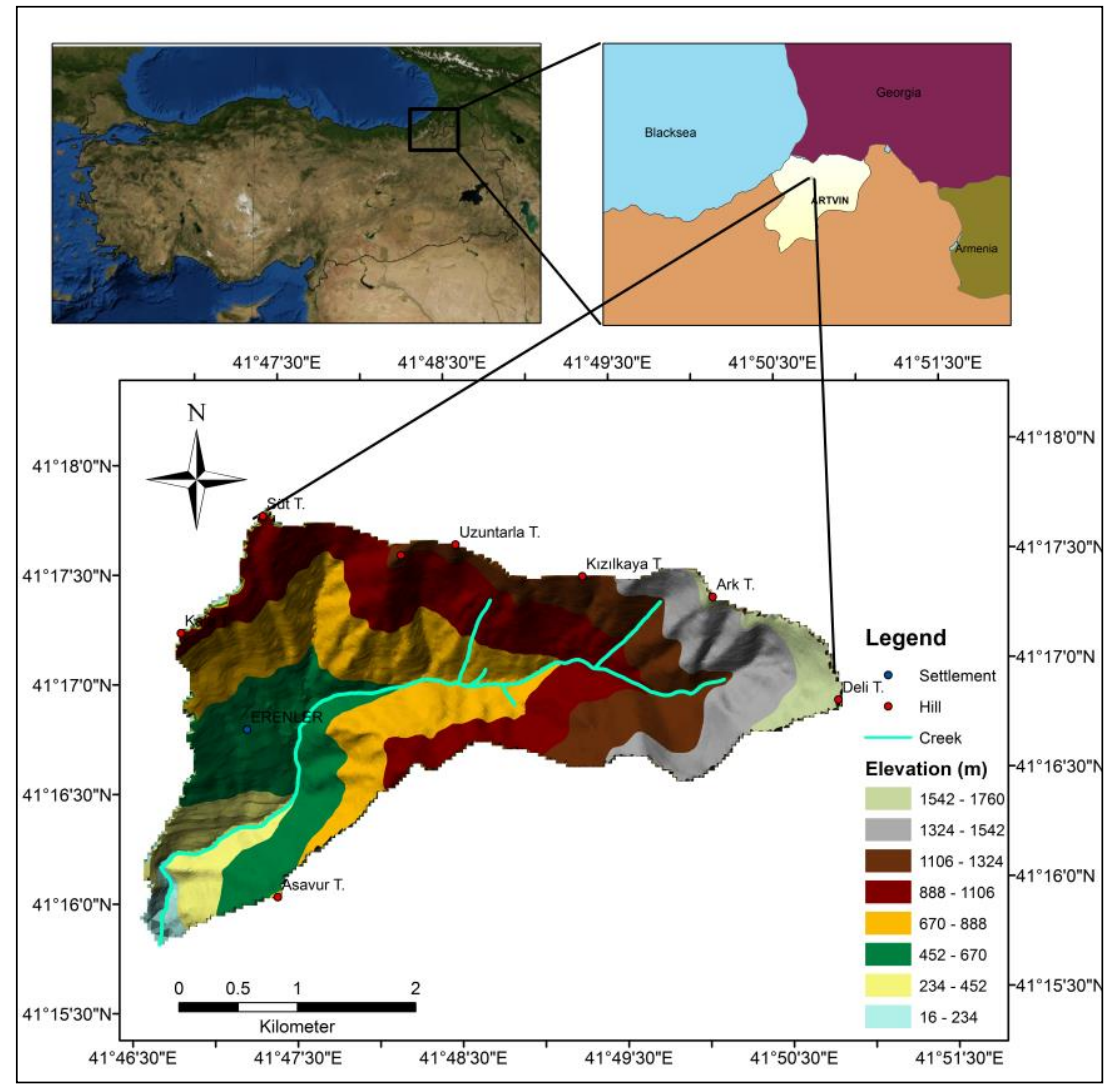

Figure 1. Geographic and Topographic Location of the Research Area

The watershed is located between $41^{\circ} 16^{\prime}$ $34^{\prime \prime}-41^{\circ} 17^{\prime} 46^{\prime \prime}$ north latitudes and $41^{\circ} 46^{\prime}$ $52 "$ - $41^{\circ} 50^{\prime} 51 "$ east longitudes. Düz Creek makes up the main section of the watershed and flows in to the Çoruh River in the river mouth. There are four different bedrock groups including claystone, basalt, andesite and rhyodacite in the watershed. The watershed area consists of 368.19 ha claystone, 277.83 ha basalt, 244.08 ha andesite and 169.29 ha rhyodacite (Figure 2a).

Forest areas constitute $78.44 \%$ of the total area with 831.06 ha and $55.32 \%$ of the forest areas are in productive forest class while agricultural areas constitute about $16.62 \%$ of it with 176.04 ha. (Figure 2b).

According to the slope map made based on the soil classification system of the study area, approximately $94.87 \%$ of the watershed has a very steep or steep slope (Figure $2 \mathrm{c}$ ). The average slope is $49.69 \%$. In the watershed, an area of 375.75 ha is included in the shady aspect group whereas an area of 683.64 ha is included in the sunny aspect group (Figure 2d). 


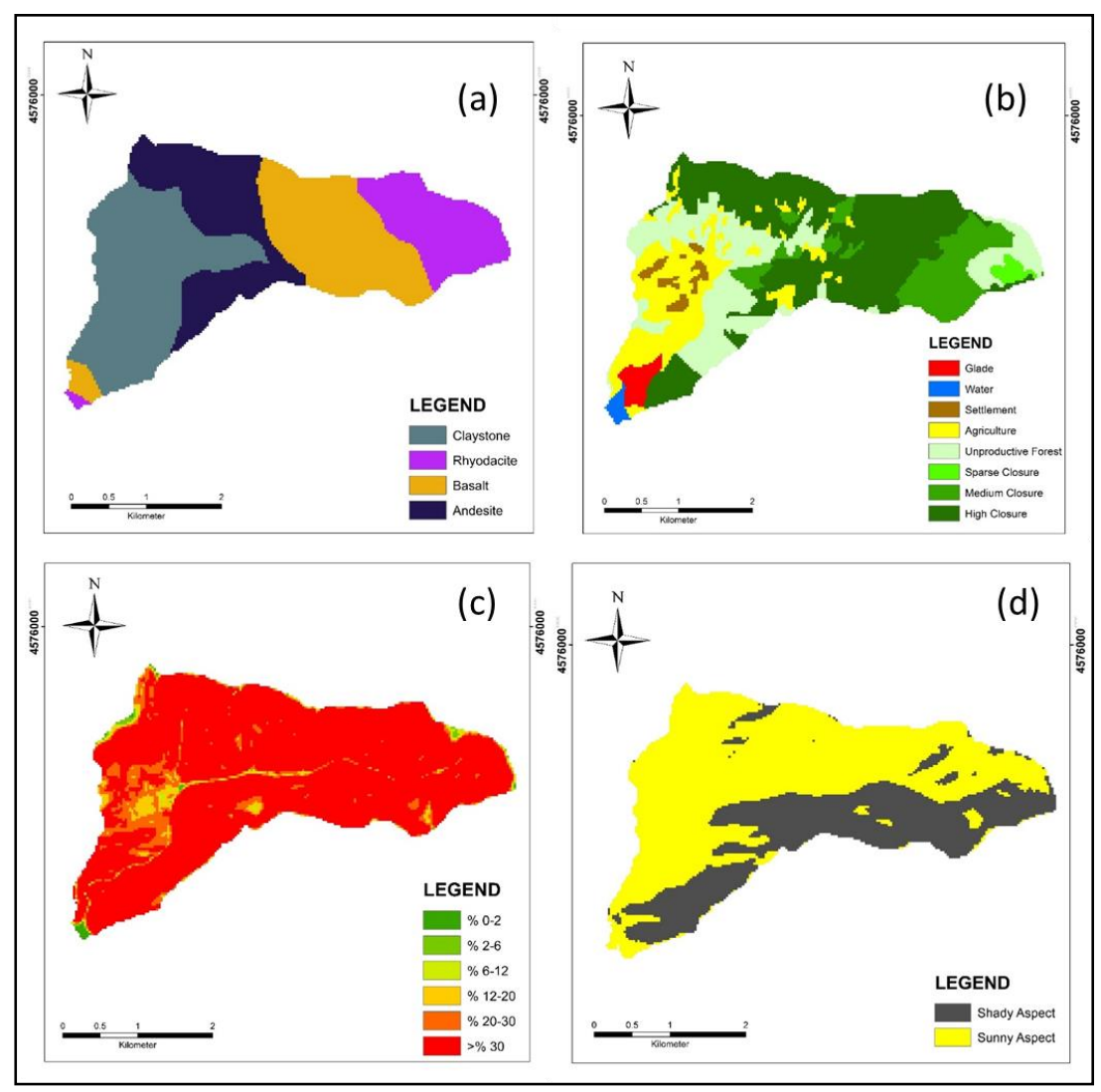

Figure 2. Study area's bedrock (a), land use, (b), slope (c) and aspect (d) maps

Erenler village with a population of 195 inhabitants (TÜiK, 2015) is located as a settlement in the watershed area. The great majority of the population is settled adjacent to the forest and in the forest. Villagers can provide enough labor for forestry operations including logging/production, transportation services, and forest regeneration works.

The slope, soil, plant management and climate files are the input parameters in the WEPP erosion model (Flanagan and Livingston, 1995). After the preparation of these files, the watershed was divided into 8 sub-watersheds to perform the model (Figure 3 ) and the average values of the watershed were measured by performing the program in these sub-watersheds.

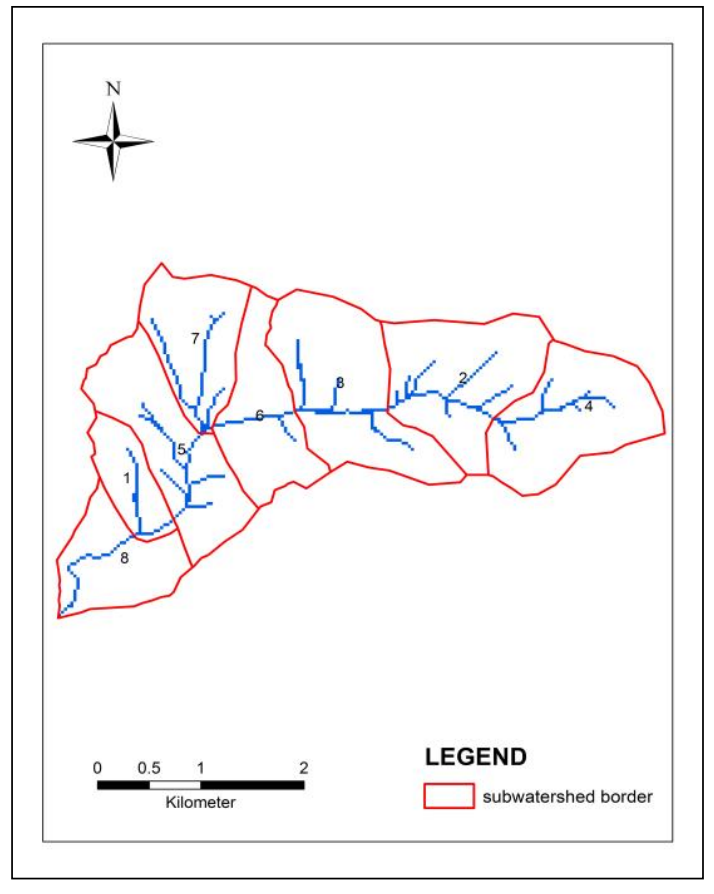

Figure 3. Boundaries of the sub-watersheds where GeoWEPP model (interface) was performed 
Slope file shows the topographical condition of the watershed or slope. In this study, the slope file was created using DEM of the watershed. In the selected watershed, a total of 18 sampling points ( 12 from forest, 6 from agricultural areas) were determined by considering the features of the parent material, land use, slope, and aspect. A total of 36 undisturbed (cylinder) and 36 disturbed (composite) soil samples from each soil depth of $0-10 \mathrm{~cm}$ and $10-30 \mathrm{~cm}$ were collected. Some physical and hydrological properties of the soils (texture, organic matter, soil depth, cation exchange capacity, albedo, hydraulic conductivity, critical shear and erodibility values, rock and saturation levels) are used in the soil file of the WEPP model. Soil file consists of (i) the calculated values during the laboratory analysis, (ii) the values measured in the field and (iii) formula and indicators specified in the WEPP user guide (Flanagan and Livingston, 1995). To create the plant management file, separate files were prepared for the agricultural, forestry and meadow lands located in the research area. The land use types of each slope in the study area were determined using forest-stand maps in the GIS environment. Each land use type was put in its place in the relevant field after the integration of the watershed with the digital elevation model (DEM) using TOPAZ. In the climate file, the average daily precipitation and the maximum precipitation values observed in standard times (30 minutes and 6 hours) which were obtained from the General Directorate of Meteorology and created according to 13-year averages were used. The average maximum temperature, average minimum temperature, average daily humidity, average daily global solar radiation, average hourly wind speed and direction, the number of monthly wind blowing based on directions were created according to the climate data of 2013 and this climate file was used in the model. The file with "par" extension created with necessary climate data calculated according to averages was converted into the file format with "cli" extension to be entered in GeoWEPP program by using the "Add Climate Location" tool in WEPP program (Flanagan and Frankenberger, 2001; USDA-ARS, 2003).

\section{Results}

As a result of applying the GeoWEPP interface to the Düz Creek Watershed, the percentage distribution of land use, the amount of soil lost from slopes and creeks in a year in tones, sediment delivery rate, total sediment yield, area of the sub-watersheds and unit area (ha) sediment yield of each watershed were presented (Table 1).

Table 1. Estimated amount of soil loss from the watershed and sediment yield

\begin{tabular}{lccccccccc}
\hline $\begin{array}{l}\text { SubWater } \\
\text { shed } \\
\text { Number }\end{array}$ & \multicolumn{2}{c}{ Land use types (\%) } & $\begin{array}{l}\text { Hillslope } \\
\text { Soil Loss } \\
\text { (ton/year) }\end{array}$ & $\begin{array}{l}\text { Channel } \\
\text { Soil Loss } \\
\text { (ton/year) }\end{array}$ & $\begin{array}{l}\text { Sediment } \\
\text { Delivery } \\
\text { Ratio }\end{array}$ & $\begin{array}{l}\text { Total } \\
\text { Sediment } \\
\text { Yield } \\
\text { (ton/yr) }\end{array}$ & Area (ha) & $\begin{array}{l}\text { Sediment } \\
\text { yield per } \\
\text { unit area } \\
\text { (ton/ha/yr) }\end{array}$ \\
\hline 1 & 11.6 & 0.2 & 88.2 & 15 & 5.2 & 1.007 & 20.4 & 57.24 & 0.4 \\
\hline 2 & 99.3 & - & 0.7 & 60 & 519.3 & 1.001 & 580.1 & 167.86 & 3.5 \\
\hline 3 & 92.4 & - & 7.6 & 11.6 & 490.2 & 1.001 & 502.5 & 187.55 & 2.7 \\
\hline $4 \_1$ & 100 & - & - & 2.2 & 37.4 & 1.001 & 39.6 & 36.16 & 1.1 \\
\hline $4 \_2$ & 100 & - & - & 0.8 & 315.2 & 1 & 316.1 & 120.7 & 2.6 \\
\hline 5 & 54.4 & - & 45.6 & 20.2 & 284.1 & 0.894 & 272.1 & 152.72 & 1.8 \\
\hline 6 & 84.4 & - & 15.6 & 22.1 & 163.4 & 0.968 & 179.5 & 120.31 & 1.5 \\
\hline 7 & 77.7 & - & 22.3 & 4.7 & 770.7 & 0.925 & 717.2 & 119.01 & 6.0 \\
\hline 8 & 31 & 33.1 & 35.8 & 40.3 & 52.8 & 1.003 & 93.4 & 97.84 & 1.0 \\
\hline Total & & & & 176.9 & 2638.3 & & 2720.9 & 1059.39 & 20.5 \\
\hline
\end{tabular}

In addition to the information in Table 1 , the amount of precipitation $(\mathrm{mm})$ that fell in each sub-watershed and how much of it was predicted as runoff as well as the annual amount of water accumulated in the watershed $\left(\mathrm{m}^{3} /\right.$ year $)$ and how much of it was discharged from the outlet of the watershed can also be seen from the result reports.

When total values obtained from the subwatersheds for the watershed with an area of 1059.39 ha were analyzed, the total soil loss occurred in the watershed was estimated to be 
2815.2 ton/year while the sediment yield was estimated to be 2720.9 ton/year. In addition, the loss that occurred on the basis of per unit area (ha) was estimated to be 2.57 ton/ha/year. Moreover, it was determined from the result reports that approximately $207 \mathrm{~mm}$ of 735 $\mathrm{mm}$ of precipitation was a runoff and the sediment delivery ratio was approximately 0.977. One of the features of the GeoWEPP interface is to provide data on the texture and organic matter $(\mathrm{OM})$ of the eroded sediment. Accordingly, for this study, the model predicted that the particle distribution of eroded sediment were $20 \%, 25 \%$ and $55 \%$ of clay, silt and sand, respectively, while the mean OM amount of the lost sediment was about $5,2 \%$ for the studied watershed.

\section{Discussion and Conclusions}

Literature shows that there are examples of different watersheds in which WEPP and other erosion prediction models were used and resulted in similar sediment and soil loss values to the predicted values gathered from this study. For example, in the Godrahav Creek Watershed, with an area of 5298.21 ha, annual average amounts of soil loss and sediment yield per unit area were predicted to be $1.73 \mathrm{t}$ ha-1y-1 and $1.86 \mathrm{t}$ ha-1y-1, respectively, by the GeoWEPP model (Ozalp, Erdoğan Yüksel \& Yıldırımer, 2017). In another study in the Artvin-Kokolet Creek watershed with an area of 4057.02 ha, it was estimated that the total soil loss was 23559 ton/year, the sediment yield was 10225.3 ton/year and the loss that occurred on the basis of per unit area (ha) was 2.52 ton/ha/year. Moreover, it was determined that approximately $209.73 \mathrm{~mm}$ of $735 \mathrm{~mm}$ of precipitation was estimated as runoff and the sediment delivery ratio was approximately 0.782 (Erdoğan Yüksel, Özalp \& Yıldırımer, 2016). In two other studies, the sediment yield occurred per unit area for the GümüşhaneTorul Dam Watershed of 212727.56 ha in size was found to be $8.66 \mathrm{ton} / \mathrm{ha} / \mathrm{year}$ (Aydın, 2007) while it was 7.42 ton/ha/year for Kahramanmaraş-Ayvalı Dam Watershed of 11531 ha (Yüksel, 2001). The higher sediment amounts found in these two studies can be related to the weak coverage of vegetation in both research sites. In addition, while the sediment yield was found as 6.95 ton/ha and the runoff was found as $23.17 \mathrm{~mm}$ in a study in the Orcan Creek Watershed, the sediment yield was measured as 5.48 ton/ha and runoff was measured as $26.58 \mathrm{~mm}$ (Yüksel, Akay, Gündoğan, Reis \& Çetiner, 2008). Moreover, in a study in which the erosion risk areas were determined by integrating GIS and USLE model in the Kahramanmaraş Plain and its surrounding, a soil loss between the range of 0-21 ton ha/yr was measured (Karabulut and Küçükönder, 2008).

In addition to modeling, studies are also carried out for the direct measurement of the soil loss and sediment yield in the field. For instance, in a study in which the effects of acacia forestations in preventing runoff and sediment delivery in Artvin-Murgul were analyzed, the runoff was measured as 263 $\mathrm{m}^{3} / \mathrm{ha}$ in the meadow area and as $18 \mathrm{~m}^{3} / \mathrm{ha}$ in the forest land right beside it, and the total amount of delivered sediment was measured as $43,6 \mathrm{~kg} / \mathrm{ha}$ in the meadow area and as 5 $\mathrm{kg} / \mathrm{ha}$ in the acacia forestation area (Tüfekçioğlu, Güner, Duman \& Küçük, 2008). According to the data obtained from the Electrical Power Resources Survey and Development Administration, the average annual sediment yield of 9 stations on the Çoruh River was disclosed to be approximately 1,8 ton/ha/year (Anonymous, 2014). Moreover, within the context of the study, the results of the Çoruh River-Altınsu (3.91 ton/ha/year) and Deviskel CreekGündoğdu (0.63 ton/ha/year) measurement stations obtained from the General Directorate of State Hydraulic Works (Anonymous, 2015) also support the results obtained by GeoWEPP interface in this study.

As it is known, in general terms, vegetation cover, topographic features, bedrock-soil properties and climate variables have been stated to be the main factors affecting the amount of soil loss in various studies (Robinson, 1977; Yüksel, Gündoğan \& Akay, 2008).

Overall. it was seen that topographic conditions including slope and the land use (forests or agricultural land) were effective on the soil loss occurred in some of the subwatersheds in the study area. In a study carried out in Hatila Valley National Park, it was stated that soil properties and climate were relatively homogeneous whereas vegetation 
cover and topography were the main factors affecting the soil loss (Eroğlu, Çakır, Sivrikaya \& Akay, 2010). It has been determined in many studies that vegetation cover has a significant effect on soil loss (ElHassanin, Labib \& Gaber, 1993; Erskine, Mahmoudzadeh, Browning \& Myers, 2003; Erskine, Mahmoudzadeh \& Myers 2002; Zhongming, Lees, Feng, Wanning \& Haijing, 2010). When the study area was analyzed in terms of land use and vegetation cover, $78.44 \%$ of the watershed consist of forest areas while $16.62 \%$ of which consist of agricultural areas and about $23.12 \%$ of the forest areas fall into very degraded class.

The ground gradient, slope length, and shape are among the most important topographical features reflecting the erosion rate (Lal, 1994). It was determined that a significant portion of $94.87 \%$ of the Düz Creek Watershed had a slope of $20 \%$ and over and that only $5.13 \%$ of the watershed contained suitable areas for agriculture. In a study in which the effect of slope on runoff and soil loss was investigated, it was determined that significant increases occurred in runoff and soil loss as the slope gradient increased. With this study, it was stated that the changes in slope gradient $\left(\leq 30^{\circ}\right.$ and $\left.>30^{\circ}\right)$ led to different results in different vegetation covers and the runoff and soil loss increased in proportion to the changes in slope gradient in the forest, meadow, and tea cultivation areas, respectively (El Kateb, Zhang, Zhang \& Mosandl, 2013).

When we analyzed the sediment yield in the study area on the basis of sub-watersheds, the highest sediment yield per unit area was found to be in the sub-watershed numbered 7 ( 6 ton/ha/year). When we evaluate it in terms of land use, $77.7 \%$ of the total area belongs to forest areas in the sub-watershed numbered 7. The rest of the area consists of agricultural areas by $22.3 \% .41 \%$ of these forest areas are included in the highly degraded forest class. In addition, it is seen that sunny aspect was dominant by $96.3 \%$ in this sub-watershed, and shady aspect covered an area of only $3.7 \%$. It was determined that this watershed was dominated by the sunny aspect at the highest level among sub-watersheds. The aspect of the land affects especially the temperature and precipitation features of that place. In this sub- watershed, $95.8 \%$ of the whole research area has a slope of $20 \%$ and over.

Moreover, the sub-watershed numbered 2 ranked second in terms of sediment yield mostly due to the fact that almost all the watershed (with 99.2\%) has a slope of $20 \%$ and over. Although there are more agricultural lands in the sub-watersheds numbered 1 and 5 , respectively, compared to other watersheds, it is considered that the lower amount of slope also affects the sediment yield in these subwatersheds. Nevertheless, a significant portion of the mentioned agricultural areas consists of the areas in which steep lands were transformed into bench terraces which are almost plain and/or close to plain by the people living in the area to create agricultural lands. Therefore, this agricultural culture across the province may be one of the reasons of a relatively less sediment yield in the watersheds numbered 1 and 5 with the higher agricultural land ratio.

With this study, it is considered that soil losses mostly occur due to the watershed's land use situation, topographic structure (the fact that it has a feature of steep land in terms of general structure) and steepness of its slope groups. Also, whether the amount of sediment formed originates from the hillslopes or channels are determinative in addition to the fact that the features of land use, slope, and aspect are the most important factors creating differences in terms of sediment yield.

The limited land suitable for agriculture in the watershed causes people living in the area to destroy the forest areas for the purpose of new agricultural areas to ensure their livelihood. Therefore, it is necessary to create new projects generating more employment opportunities and to comply with the principle of land classification by taking measures preventing the soil loss in land use to decrease this negative pressure on forests.

It is necessary to make projections of the soil erosion in watersheds through various scenarios for the future by supporting the studies of adapting models such as RUSLE and WEPP, which have been increasingly used in recent years in the calculation of soil loss, to all main watersheds. Moreover, the use of detailed data and maps of the land use, climate, slope, soil and other physiographical factors obtained for the implementation of the 
WEPP model to carry out more similar scientific studies should be supported.

\section{Acknowledgment}

Part of this article's results was presented in the International Forestry Symposium (IFS 2016 in Kastamonu, Turkey) and only the abstract was published in Abstract Book.

\section{References}

Anonymous (2014). Orman ve Su İșleri Bakanlığı, OGM, Çoruh Nehri Havzası Rehabilitasyon Projesi, Erozyon ve CBS İzleme 3. Ara Raporu (1 Kasim 2013-30 Nisan 2014). [Ministry of Forestry and Water Affairs, OGM, Coruh River Watershed Rehabilitation Project, Erosion and CBS Monitoring $3^{\text {rd }}$ Interim Report (November 1, 2013 - April 30, 2014).]

Anonymous (2015). DSİ Genel Müdürlügüü, Etüt, Planlama ve Tahsisler Dairesi Başkanlığı, Su ve Toprak Laboratuvarı Şube Müdürlügü, Sediment Gözlem İstasyonu Verileri.

Anonymous. (2018). Dinamik Erozyon Modeli ve İzleme Sistemi, Türkiye $\mathrm{Su}$ Erozyonu İstatistikleri, Teknik Özet. ÇEM Genel Müdürlüğü Yayınları, Ankara.

Ascough II, J. C., Nearing, M. A., Baffaut, C. \& Liu, B. Y. (1997). The WEPP Watershed Model: I. Hydrology and Erosion. Transactions American Society of Agricultural Engineers, 40(4), 921-933.

Aydın, M. (2007). Gümüşhane-Torul Barajı Yăğı̧̧ Havzasından Taşınan Toprak Miktarının Wepp Ortamında Belirlenmesi ve Çözümleri Üzerine Araştırmalar. (Doktora Tezi). [Studies on the Determination and Solutions of the Amount of Soil Carried from Gümüşhane-Torul Dam Watershed. (Ph.D.)] Karadeniz Teknik Üniversitesi, Fen Bilimleri Enstitüsü, Trabzon.

Baffaut, C., Nearing, M. A., Ascough II, J. C. \& Liu, B. (1997). The WEPP Watershed Model: II. Sensitivity Analysis and Discretization on Small Watersheds, Transactions American Society of Agricultural Engineers, 40(4), 935943.

Başyiğit, L. \& Dinç, U. (2003). Eğirdir Gölü Su Toplama Havzasında Oluşan Toprak Kayıplarını Tahmin Etmeye Yönelik Bir Çalışma. [A Study on Predicting the Soil Losses in Eğirdir Lake Catchment Watershed.] Çukurova Üniversitesi Ziraat Fakültesi Dergisi, 18(2), 51-60.

El-Hassanin, A. S., Labib, T. M. \& Gaber, E. I. (1993). Effect of vegetation cover and land slope on runoff and soil losses from the watersheds of Burundi. Agriculture, Ecosystems \& Environment, 43(3-4), 301-308.
El Kateb, H., Zhang, H., Zhang, P. \& Mosandl, R. (2013). Soil erosion and surface runoff on different vegetation covers and slope gradients: A field experiment in Southern Shaanxi Province, China. CATENA, 105(0), 1-10.

Erdoğan Yüksel, E., Özalp, M. \& Yıldırımer, S. (2016). Using A Geospatial Interface (GeoWEPP) To Predict Soil Loss, Runoff And Sediment Yield Of Kokolet Creek Watershed, International Journal of Ecosystems and Ecology Sciences, 6(3), 437-442.

Eroğlu, H., Çakır, G., Sivrikaya, F. \& Akay, A. E. (2010). Using high resolution images and elevation data in classifying erosion risks of bare soil areas in the Hatila Valley Natural Protected Area, Turkey. Stochastic Environmental Research and Risk Assessment, 24, 699-704.

Erskine, W. D., Mahmoudzadeh, A., Browning, C. M. \& Myers, C. (2003). Sediment yields and soil loss rates from different land uses on Triassic shales in western Sydney, NSW. Australian Journal of Soil Research, 41(1), 127-140

Erskine, W. D., Mahmoudzadeh, A. \& Myers, C. (2002). Land use effects on sediment yields and soil loss rates in small basins of Triassic sandstone near Sydney, NSW, Australia. CATENA, 49(4), 271-287.

Flanagan, D. C. \& Livingston, S. J. (1995). WEPP User Summary (USDA-Water Erosion Prediction Project): National Soil Erosion Research Laboratory, Report No:11.

Flanagan, D. C. \& Nearing, M. A. (1995). USDAWater Erosion Prediction project: Hillslope profile and watershed model documentation. USDA-ARS National Soil Erosion Research Laboratory, West Lafayette.

Flanagan, D. C. \& Frankenberger, J. (2001). Format of Cligen weather station statistics input files, for Cligen versions $4.1-5.1$ as of 6/2001 (D.C. Flanagan), updated 12/11/2008 Jim Frankenberger.

Foster, G. R. \& Lane, L. J. (1987). User requirements UDSA-Water Erosion Prediction Project (WEPP), NSERL Report no. IUSDAARS National Soil Erosion Research Laboratory, West Lafayette, IN 47097-1196.

Garbrecht, J. \& Martz, L. W. (1999). TOPAZ: An Automated Digital Landscape Analysis Tool for Topographic Evaluation, Drainage Identification, Watershed Segmentation and Subcatchment Parameterization; TOPAZ Overview. USDA-ARS Publication No. GRL 9-I.

Hacisalihoğlu, S., Kalay, H. Z. \& Oktan, E. (2008). Toprak Aşınımı (Erozyon) Benzetim (Simülasyon) Modelleri. [Soil Erosion and 
Simulation Models.] Orman Mühendisleri Odası Dergisi, 45(10-11-12), 40-45.

Karabulut, M. \& Küçükönder, M. (2008). Kahramanmaraş Ovası ve çevresinde CBS kullanılarak Erozyon Alanlarının Tespiti. Kahramanmaraş Sütçü İmam Üniversitesi Fen ve Mühendislik Dergisi, 11(2), 14-22.

Lal, R. (1994). Soil erosion research method, 2nd edn. Soil and Water Conservation Society, Ankeny, IA, USA., 352.

Nearing, M. A., Foster, G. R., Lane, L. J. \& Finkner, S. C. (1989). A process based soil erosion model for USDA-Water Erosion Prediction Project technology. Transactions American Society of Agricultural Engineers, 32(5), 1587-1593.

Özalp, M., Erdoğan Yüksel, E. \& Yıldırımer, S. (2017). Subdividing Large Mountainous Watersheds into Smaller Hydrological Units to Predict Soil Loss and Sediment Yield Using the GeoWEPP Model, Polish Journal of Environmental Studies, 26 (5), 2135-2146.

Robinson, A. R. (1977). Relation between soil erosion and sediment delivery, Proceedings of the Paris Symposium On Erosion And Solid Matter Transport In Inland Waters, Dorking Surrey. UK., 122, 159-167.

Tüfekçioğlu, A., Güner, S., Duman, A. \& Küçük, M. (2008). Murgul-Akasya Ağaçlandırmalarının Yüzeysel Akış ve Sediment Taşınmasını Önlemedeki Etkileri ve Bunun Su Yönetimi-Kuraklık Ilişkileri Bakımından İrdelenmesi. [Effects of MurgulAkasya Afforestation in Preventing Surface Runoff and Sediment Transport and Investigating it in terms of Water Management - Drought Relations]. Kuraklık ve Su Yönetimi Bildiriler Kitabı , 15-16 Mayıs, Ankara,, 254259.

TÜİK, (2015). Adrese Dayalı Nüfus Kayıt Sistemi (ADNKS) Veri Tabanı, Şehir, Belde ve Köy Nüfusları.

USDA-ARS (2003). Using Climate Data in the WEPP Windows Interface, USDA-ARS National Soil Erosion Laboratory September 25, 2003 (Updated May 19, 2006).

Wischmeier, W. H. \& Smith, D. D. (1965). Predicting rainfall-erosion losses from cropland east of the Rocky Mountains: guide for selection of practices for soil and water conservation, (Vol. 282). US Department Agricultural Handbook.

Yüksel, A. (2001). K.Maraş Ayvalı Barajı Yağış Havzasının CBS (Coğrafi Bilgi Sistemi) Ortamında Havza Amenajmanı Bakımından Planlanması Üzerine Araştırmalar. (Doktora Tezi). [Studies on Planning K.Maraş Ayvalı Dam Watershed in terms of Watershed
Management in GIS (Geographic Information System) Environment. (Ph.D.)]. K.T.Ü. Fen Bilimleri Enstitüsü, Trabzon.

Yüksel, A., Akay, A. E., Gündoğan, R., Reis, M. \& Çetiner, M. (2008). Application of GeoWEPP for Determining Sediment Yield and Runoff in the Orcan Creek Watershed in Kahramanmaras, Turkey. Sensors, 8, 12221236.

Yüksel, A., Gündoğan, R. \& Akay, A. E. (2008). Using the remote sensing and GIS technology for erosion risk mapping of Kartalkaya dam watershed in Kahramanmaras, Turkey. Sensors, 8, 4851-4865.

Zhongming, W., Lees, B. G., Feng, J., Wanning, L. \& Haijing, S. (2010). Stratified vegetation cover index: A new way to assess vegetation impact on soil erosion. CATENA, 83(1), 87-93. 